\title{
The Ring and the Books
}

Do you see this ring?

$\sim$ Robert Browning, The Ring and the Book (1868)

Thou shalt not ever bid on anything

When it's so lucrative to form a ring.

$\sim$ Ian Jackson, An Antiquarian ABC (1998)

IN THE AUCTION TRADE, a "ring" refers to a group of buyers who collude before a sale to keep prices down by agreeing not to compete against one another. When the sale is over, all of the items that have been "ringed" are then reauctioned (the "knockout") among the members of the ring in a private setting, and each more or less gets what he or she really wanted at a much lower price than would have been the case if there been competitive bidding. Even those not interested in any particular item make some money in the process. It is certainly an unfair practice for both the consigner, who has suffered because of the low prices that are realized, and the auction house, since it receives a lower commission than would have otherwise been paid. While admittedly it may be somewhat difficult to feel sorry for the auction houses, which collect money from both ends in an attempt to discover new ways to add to their bank balances, it is certainly unfair to the consigners.

Book auctions long suffered from the influence of rings. The practice was outlawed in England following the notorious 1919 Ruxley Lodge sale (about which Arthur Freeman and Janet Ing wrote a fascinating book published in $1990^{1}$ ), with the passage of The Auctions (Bidding Agreements) Act in 1927. The practice is also illegal in most western countries. It goes against the restraint of trade provisions in the U.S. Sherman Act of 1890, and it smacks also of a cartel or price-fixing. Price-setting schemes of various kinds keep attracting manufacturers, despite the fact that the offenders continue to get caught, to no one's real surprise. Even to this day, rumors persist of rings in the English book trade. It is said that certain booksellers

1. The act $(17 \& 18$ Geo. 5, c. 12) can readily be found printed in The Complete Statutes of England Classified and Annotated (London: Butterworth \& Co., 1929), I: 478-79. The Freeman and Ing book is Anatomy of an Auction: Rare Books at Ruxley Lodge, 1919 (London: The Book Collector, 1990). Stuart Bennett provides some useful citations about rings in his article "Fine Art Auctions and the Law: A Reassessment in the Aftermath of Cristallina," Columbia-VLA Journal of Law \& the Arts 16, 3 (Spring 1992), 271 n64. (I am grateful to Stuart Bennett for his comments on my paper.) 
are blackballed and thereby prevented from joining the Antiquarian Booksellers Association (ABA) because they are known to be involved in a ring. John Carter's $A B C$ for Book Collectors notes that, in 1956, the ABA formally denounced rings and forbade ABA members to take part in them. ${ }^{2}$

I had never considered any of my activities as Head Librarian of The William Andrew Clark Memorial Library to be remotely similar to those of a ring of booksellers, until Peter Howard, the owner of Serendipity Books in Berkeley, California, accused me and some of my colleagues of being involved in a ring. How so? Well, it has to do with collection development and the buying of old books. I believe that, given limited money for book-buying, and especially given the fact that I run a rare book library in a large urban environment where there are lots of other good rare book libraries within an easy drive (depending on traffic), I can and should take into account the presence of other copies of a particular book in the collections near mine when making collection development decisions. For example, if I am offered a copy of Roger Coke's A Discourse of Trade (London, 1670) at £1500 and find, as I did recently, that there is already a copy of this book at the Huntington Library in nearby San Marino, then I feel it unnecessary to buy the book for the Clark Library, despite the fact that English books printed between 1640 and 1800 are one of our areas of specialization. The same logic would apply to a Gehenna Press book or to Coffee: A Bibliography (2002), which was sent to market at almost a thousand dollars.

The Clark Library is in a somewhat unusual position. It is a UCLA library located twelve miles from the main UCLA campus. I would never dream of acquiring the Scripps College Press books or the lovely books of the Ninja Press in Sherman Oaks, because the Department of Special Collections on the main campus has a standing order for these books. I will, however, admit that certain limited areas of collecting are exempt from this restraint. The Clark has a uniquely rich collection of the works of Oscar Wilde, and we basically attempt to buy everything, even those books already at UCLA, or the University of Southern California library, or anywhere else locally. I make something of an exception for the works of Sir Isaac Newton as well, because the Clark's holdings are rich. Where certain often-examined reference books are concerned, I will duplicate the holdings of other campus libraries. Recently, I swallowed hard and bought both the English and the Hebrew volumes of the Catalogue of Books Printed in the Fifteenth Century Now in the British (Museum) Library (BMCXV), at $\$ 1,250$ each, to complete our set, knowing full well that UCLA's Charles E. Young Research Library would also acquire them. On the whole, however, I will not knowingly duplicate a reasonably expensive book if it is already held in a neighboring library. It seems to me to make far more sense economically to acquire books that no one else nearby

2. John Carter and Nicolas Barker, $A B C$ for Book Collectors, 8th ed. (New Castle, Del.: Oak Knoll Press; London: The British Library, 2004), 192. 
owns. I have limited funds, and if I had to choose between, say, the Ashendene Press Dante that is already in the collections at Occidental College and Loyola Marymount University but is not at the Clark (William Andrews Clark, Jr. owned one but seems to have given it away), and A.R. Solger's Bibliotheca Anonymiana (Nurnberg, 1738), the closest copy of which is at Berkeley, I don't see that there is really a choice to be made. The Solger wins hands down.

What is there to object to in such decisions? Well, first of all, with older books, some of the antiquarian booksellers believe that this is setting a definite and unwanted limitation upon their market for old books. For printers, the same feeling arises but it is more personal. Whether or not a printer depends on his or her printing for a living (and few, let us admit it, do), he or she feels that being limited to the sale of just one copy in a place as rich in libraries as Los Angeles restricts his or her ability to do business in a nasty way.

From the reader's point of view, the practice results in a trip to more than one library to study a particular topic, which can certainly be somewhat inconvenient. From a more theoretical collection development point of view, the resulting split collections are full as a complementary whole, but incomplete in their separate locations. No one likes "gaps." If you own the first, third, fourth, and fifth editions of Moll Flanders, but you lack either of the variant imprints of the second edition (both surprisingly rare books, much scarcer than the first edition), that "gap" somehow feels like a hole in your heart, even if there is a copy down the street at another library. If you collect seventeenth-century astrology books but lack William Lily's Fore-warn'd, fore-arm'd (1682), no matter how many other Lily books you have, and despite the presence of the title in a sister institution nearby, the omission feels somehow embarrassing and the title is likely to be on one of your want lists. But why? The next Lily scholar or Defoean who walks through the door may be slightly annoyed to have to go on, after exhausting your collection, to a second or even a third library; but that is surely a minor inconvenience. There will be some other scholar who will be delighted that you own another book-like the first French edition of Bunyan's Holy War (1796) that I acquired recently, a unique survivor that was printed on the Isle of Guernsey, of all places - that was purchased because it is not in any other library in the city. The research emotions of scholars are, in any case, often selfish, and you cannot please them all, all of the time. Trying to fill the gaps in a collection has always seemed to me a senseless and unrewarding goal in life for a librarian; if the books being plugged into those gaps constitute editions or works that can be consulted elsewhere close by, then dreariness is compounded with uselessness and budgetary waste.

I actually think that my practice has started to be adopted by colleagues at other Los Angeles libraries, as I now hear from booksellers that a book was refused by 
the Huntington or the Getty Research Institute "because the Clark already owns it." This is a sea-change and rather gratifying. Some years ago, one of the Huntington's rare book librarians came to the Clark to examine a copy of a very rare late seventeenth-century English book on ornamental iron work, Jean Tijou's Nouveau livre de desseins inventé et dessiné (London, 1693). The revised edition of Wing gives only nine locations for this handsome oblong book. The Clark's is in excellent condition, but there is a minor stain in the gutter. The Huntington librarian decided that the stain was reason enough to buy a copy for his library, despite the high price (it was four, if not five figures). Although in the end, I don't think that the Huntington did buy it, the point is that the culture at that time supported the idea of doing so, whether or not there was a copy at the Clark. Now this culture seems to have changed; does this make us part of a ring?

As previously mentioned, both the UCLA Department of Special Collections and the Clark buy contemporary press books. When printers come to make a presentation, as they regularly do, the UCLA librarian and I (or one of my staff) chat afterwards and sort out who will buy what. Neither of us wants to duplicate the other's holdings, since we may be physically remote but work for the same institution. (Neither of us, incidentally, is spending public money, so our reluctance is not based on that sort of fiscal earnestness.) Does this activity constitute a ring as well?

I don't believe so. I am not trying to depress competition or keep prices down. I make no profit from the practice. With the limited acquisition funds available to me, I am always making choices - sometimes difficult choices-among things offered for sale, because there are and always will be more books to buy than money with which to buy them. How I make those choices is a complicated process, and finding out whether other copies are already on the shelves of sister institutions is only one of the ways I winnow down the mountain of what is offered to the molehill of what I have the money actually to purchase. Even if a book is not necessarily overpriced (though that does sometimes happen), it may be just too expensive in

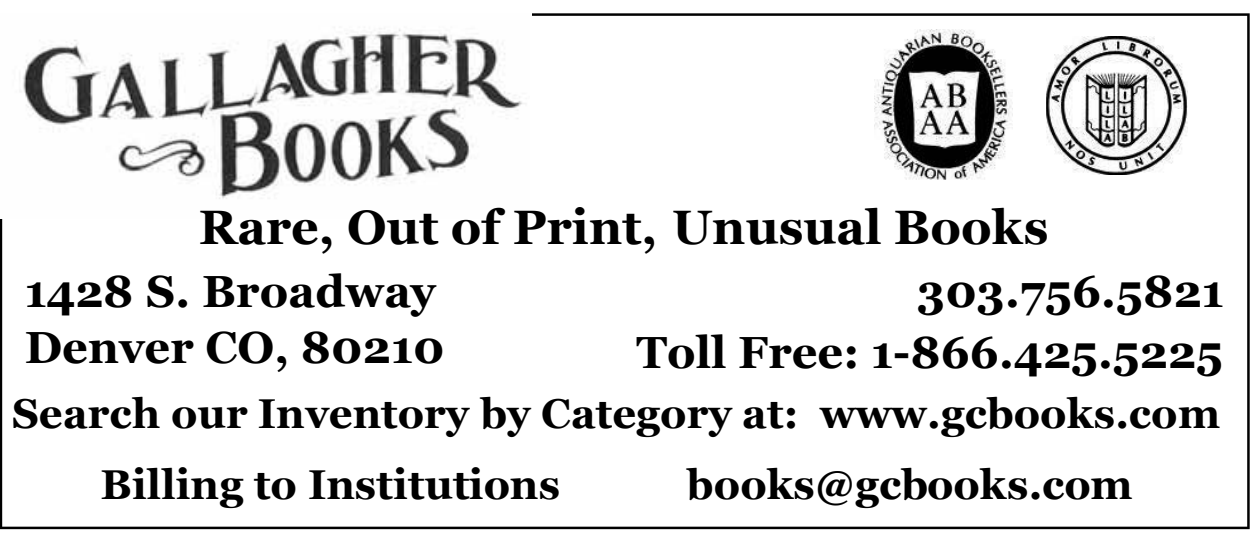


terms of my available funds, too marginal to the collection, not in good enough condition, and so on.

Editions and variant printings matter sometimes, but at other times are less significant and thus not worth spending money on. As an example, I was recently offered the ordinary edition of the Foulis Press Caesar (1750) for $\$ 1,500$ and decided against it because the Clark already owns the large paper issue, which has a different pagination. Booksellers and collectors, as well as bibliographers, pay a lot of attention to minor variants in books of the hand press period, and so it would sound crass - even philistine - to say that a good library of eighteenth-century English books really only needs one variant of the first edition of Boswell's Life, not several. But the truth is that the vast majority of readers who come to a rare book library do not know much about the finer points of antiquarian bibliography and do not care whether they are reading the "give" issue or the "gve" issue of the book. (Of course, that particular book is rarely called up in any case, because it is so readily available in other forms. That is another home truth that is also considered impolite to mention in the company of book people.) A text as complicated in its evolution as, say, Burton's Anatomy of Melancholy (1642), or Whitman's Leaves of Grass (1855), should certainly be collected beyond the first or the last lifetime edition. But many texts vary not at all from the first edition to the umpteenth, and the decision about whether or not to collect them all depends on many factors.

In sum, every purchase needs to be reasoned through, and every purchase is made by weighing several factors, of which duplication within a geographical area, however constituted, is surely one. In a global sense, five major libraries within easy distance of each other have a certain accumulation of money to spend on old books, and they will spend it. What they spend it on, from the booksellers' point of view, really ought to be irrelevant, for if it is not spent on one book by $\mathrm{X}$ because $\mathrm{Y}$ already owns a copy, it will be used by $\mathrm{X}$ to purchase something that Y doesn't own. Either way, the booksellers will get the money. The printers have, perhaps, more of a case, because if there are ten libraries that collect the book arts and only one buys a particular new objet, then it is true that the market has been restricted. My friend Peter Koch, the Berkeley printer, complained about this once in a letter:

I hear that there is a strange policy in the basin that there should only be one copy of any book by Peter Koch in the LA region. Duplicates are to be frowned upon and scholars should damn well drive the extra miles to UCLA etc. Seems a stingy policy considering tornadoes, fire and tsunamis will gobble up everything eventually anyway. 
Perhaps it is a strange policy, although if earthquakes and fires ultimately destroy all the books in the future anyway, then they will destroy seven copies of Koch's wonderful Parmenides (2003) as readily as one. Of course, Peter would have been paid for seven copies, so one can understand his concern. He has to eat, after all. Yet I still think that the responsible use of funds has to take precedence where collection building is concerned. To separate multiple collections on the same subject (like the contemporary book arts) rationally, so that X collects Koch and Y collects Ninja Press, is only sensible library economy, to use an old-fashioned expression.

Where special collections librarians as a whole are concerned, however, I have to admit that not all of them are very interested in library economy's view of this issue. Most good rare book librarians have a collector's instinct and are not necessarily willing to turn things down because other copies are located nearby. If they want the book, and if it fits their collecting mandate, they will buy it irrespective of anything else. One of my UCLA colleagues, who buys materials mainly in the sciences and medicine, shrugs off the fact that she regularly buys old books already owned by the Huntington Library. She believes it is easier for UCLA faculty and students to read the book in her shop than to send them to San Marino, where they

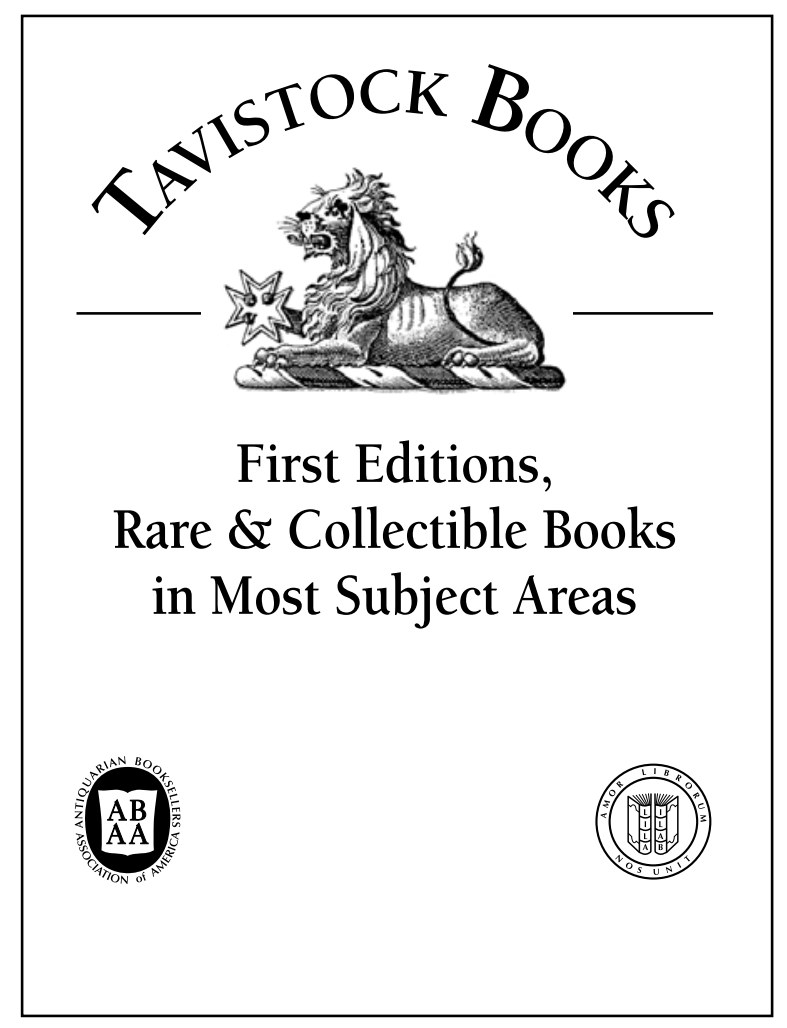


may not actually be all that welcome unless they are advanced graduate students or have a letter of introduction from a mentor. There is some justification for that view of the matter.

Good collections get to be good, at least in part, by fierce determination to get good material, even at the expense of a sister institution or at the risk of duplicating collections in the neighborhood. I cannot really reject that instinct, because it seems to be a sine qua non in my trade, and some of my trade's most notable collection builders operate by stealth and lack of ruth, rather than in the spirit of cooperation. But there is an old-guard feel to such an approach, a kind of holdover from the days when material was cheaper and more plentiful and there were fewer players. Now, as in so many other arenas, cooperation seems a much more defensible approach. For one thing, funders (who are playing an ever-increasing role in rare book collection building) like cooperation. The National Endowment for the Humanities seems to have lost interest in physical books, but many foundations that do still support the acquisition of books like to know that their dollars are being spent in a cooperative manner and without duplicating existing resources.

I understand that my arguments will not hold much water with the antiquarian booksellers. A publisher friend of mine once told me, vis-à-vis the archives of publishers and writers, that there are two of everything and that everything can be sold twice. (He was thinking of letters and retained copies, as well as multiple copies of manuscripts.) Booksellers are happy to sell two of everything, or three, or four, for that matter. It is, after all, their life's blood; who can blame them?

INDEX TO ADVERTISERS

